\title{
Changes of Plasminogen Activator Activity under Heat Stress Condition in Porcine Endometrium
}

\author{
Yong Hwangbo ${ }^{1}$, Hee-Tae Cheong ${ }^{2}$ and Choon-Keun Park ${ }^{1, *}$ \\ ${ }^{1}$ College of Animal Life Sciences, Kangwon National University, Chuncheon 24341, Korea \\ ${ }^{2}$ College of Veterinary Medicine, Kangwon National University, Chuncheon 24341, Korea
}

Received September 11, 2019

Revised September 16, 2019

Accepted September 17, 2019

\section{*Correspondence}

Choon-Keun Park

E-mail: parkck@kangwon.ac.kr

ORCID

https://orcid.org/0000-0003-2786-8814

\begin{abstract}
The aim of this study was to investigate effect of heat stress on expression levels of plasminogen activators (PAs) related mRNAs and proteins, and changes of PAs activity in porcine endometrial explants. The endometrial explants (200 $\pm 50 \mathrm{mg}$ ) were isolated from middle part of uterine horn at follicular phase (Day 19-21) and were pre-incubated in serum-free culture medium at $38.5^{\circ} \mathrm{C}$ in $5 \% \mathrm{CO}_{2}$ for $18 \mathrm{~h}$. Then, the tissues were transferred into fresh medium and were cultured at different temperature $\left(38.5,39.5,40.5\right.$ or $\left.41.5^{\circ} \mathrm{C}\right)$ for $24 \mathrm{~h}$. The expression level of urokinase-type PA (UPA), type-1 PA inhibitor (PAI-1), type-2 PAI (PAI-2), and heat shock protein-90 (HSP-90) mRNA were analysis by reverse-transcription PCR and proteins were measured by western blotting. The supernatant were used for measurement of PAs activity. In results, mRNA and protein levels of HSP-90 was higher in $41.5^{\circ} \mathrm{C}$ treatment groups than other treatment groups $(p<0.05)$. The expression of UPA, PAI1 , and PAI-2 mRNA were slightly increased by heat stress, however, there were no significant difference. Heat stress condition suppressed expression of active UPA and PAI-2 proteins $(p<0.05)$, whereas PAl-1 protein was increased $(p<0.01)$. Although PAI-1 protein was increased and active UPA was decreased, PAs activity was greatly enhanced by exposure of heat stress $(p<0.05)$. These results suggest that heat stress condition could change intrauterine microenvironment through regulation of PAs activity and other factors regarding with activation of PAs might be regulate by heat stress. Therefore, more studies regarding with regulatory mechanism of PAs activation are needed.
\end{abstract}

Keywords: endometrium, heat shock protein, heat stress, pigs, plasminogen activators activity

\section{INTRODUCTION}

In the pig industry, reproductive performance is one of important factors that are directly influenced to economic benefit, and it is affect by environmental and genetic factors. Furthermore, another factors such as feed, breed, temperature, light and nutrient condition, and water consumption influenced to reproductive performance
(Peltoniemi et al., 1999). Pigs have a thick subcutaneous fat and small number of sweat glands, and these physiological features led to higher sensitivity of pig than other species and seasonal infertility (Love et al., 1993). Continuous exposure into high temperature is caused to disrupt various physiological and cellular phenomenon including redistribution of blood flow, function of germ cells, embryo development, delayed puberty of gilts and a reduced 
litter size during summer (Claus and Weiler, 1985; Prunier et al., 1996; Li et al., 2015).

A increasing of temperature in the testis led to reduced sperm motility and concentration, and increase population of abnormal spermatozoa in ejaculate (Hansen, 2009). Also, heat stress induced hypoxia and oxidative stress in cells through generation of reactive oxygen species (ROS), and it lead to apoptosis and DNA fragmentation in spermatogenic cells (Paul et al., 2009). Paul et al. (2009) reported that fertilized oocytes with heat stressexposed sperm had lower developmental competence than fertilized oocytes with normal sperm in mice. Female reproductive events are disrupted by heat stress as well as male reproduction. Heat stress exposure in heifers and lactating cows in summer was caused reduced fertilization and early embryonic development (Sartori et al., 2002). Moreover, heat stress could alter steroid secretion, gene expression, and follicle growth that are caused to disrupt oocyte maturation (Roth et al., 2001). Maternal heat stress could induced generation of ROS in female reproductive tracts and these might be involved in regulation of uterine environments.

As one of serine protease, plasminogen activators (PAs) convert inactive plasminogen to active plasmin, and this proteases are divided two form as urokinase-type (uPA) and tissue-type (tPA). Activation of PAs was regulated by their specific inhibitors (type-1 PA inhibitor, PAI-1; type2 PA inhibitor, PAI-2). These PAs and their inhibitors are secreted by variety of cells, and they play an important role in tissue remodeling via degradation of fibrin and ac- tivation of matrix metalloproteinase. These physiological roles of PAs system are closely involved in various reproductive phenomenon including angiogenesis, implantation, placentation, ovulation and fertilization (Bazer, 2013). In our previous study (Hwangbo et al., 2016), heat stress on porcine uterine epithelial cells slightly decreased two-type of PAs and PAIs and significantly increased expression of tPA protein. However, monolayer cultured cells in in vitro environment lose their physiological function and this model is not suitable for investigation of uterine biology. Therefore, we used explant culture model for more precise reaction of uterus under heat stress condition, and the aim of this stud was to investigate effect of heat stress on expression levels of plasminogen activators (PAs) related mRNAs and proteins, and changes of PAs activity in porcine endometrial explants.

\section{MATERIALS AND METHODS}

\section{Endometrial explant culture and induction of heat stress}

All procedures that involved the use of animals were approved by the Kangwon National University Institutional Animal Care and Use Committee (KIACUC-09-0139). The uterus was collected from a local slaughterhouse and was transported to the laboratory within $2 \mathrm{~h}$ on ice. Estrous cycle of uterus was identified by morphology of follicles and uterus at follicular phase (Day 19-21), which has up to $6 \mathrm{~mm}$ in a diameter of antral follicles, was used. Porcine uterus was washed twice using Hank's Balanced Salt

Table 1. Primer sequences used for RT-PCR

\begin{tabular}{|c|c|c|c|c|}
\hline Gene & Primer sequence $\left(5^{\prime} \rightarrow 3^{\prime}\right)$ & Product size (bp) & Annealing temp. & Accession number \\
\hline \multirow[t]{2}{*}{ UPA } & F: CCTACAAGTACTTCTC & 460 & $55^{\circ} \mathrm{C}$ & NM_213945 \\
\hline & R: GCAAACCAAGGCTGGTTTCTC & & & \\
\hline \multirow[t]{2}{*}{$t P A$} & F: AGGAGGCCTCTATGCTGACA & 544 & $59^{\circ} \mathrm{C}$ & NM_214054 \\
\hline & R: GGCACACAGCATATTGTTGG & & & \\
\hline \multirow[t]{2}{*}{ PAl-1 } & F: GCCGATGCCATCTTCGTGCA & 400 & $60^{\circ} \mathrm{C}$ & NM_213910 \\
\hline & R: TCCAGGATGTCGTAGTAACGGC & & & \\
\hline \multirow[t]{2}{*}{ PAl-2 } & F: CGACTCAGCGCAAATCAGTA & 360 & $55^{\circ} \mathrm{C}$ & XM_003121697 \\
\hline & R: GTCATTCTTTCCCGACATGC & & & \\
\hline \multirow[t]{2}{*}{ HSP-90 } & F: CGGAAATCGCCCAGTTGATG & 286 & $59^{\circ} \mathrm{C}$ & NM_213973.2 \\
\hline & R: ATGAACGCCTTGGTCCCAGA & & & \\
\hline \multirow[t]{2}{*}{ ACTB } & F: AAATGGGCACGTTGTGGGTG & 159 & $60^{\circ} \mathrm{C}$ & XM_003124280 \\
\hline & R: AGGCCAACCGGGAGAAGATG & & & \\
\hline
\end{tabular}

UPA, urokinase-type plasminogen activator; tPA, tissue-type plasminogen activator; $P A /-1$, type-1 plasminogen activator inhibitor; $P A I-2$, type-2 plasminogen activator; HSP-90, heat shock protein-90; ACTB, actin-beta. 
Solution (HBSS) containing $0.1 \%(\mathrm{w} / \mathrm{v}) \mathrm{BSA}$ and uterine horn was separated from connective tissues. Endometrial tissues $(200 \pm 50 \mathrm{mg})$ in middle part of uterine horn were isolated from perimetrium and pre-incubated in serum-free Dulbecco's modified eagle's medium/Ham's F-12 nutrient mixture (DMEM/F-12) containing $0.1 \%(\mathrm{v} / \mathrm{v})$ antibiotic-antimycotic and $20 \mu \mathrm{g} / \mathrm{mL}$ amphotericin B. To induce heat stress, tissues were incubated at 38.5 (control group), 39.540 .5 and $41.5^{\circ} \mathrm{C}$ for $24 \mathrm{~h}$ after pre-incubation.

\section{Reverse transcription-PCR}

To extract total RNA from cultured tissues, trizol reagen (Takara, Japan) was used and cDNA was synthesized using Maxime TR Premix (iNtRON Biotechnology, Korea) according to manufacturer's protocol. Concentration of total RNA and cDNA was quantified by Nanodrop 2000 (Thermo Scientific Nanodrop, Wilmington, DE, USA). All of primers for specific sequence in $U P A, t P A, P A I-1, P A I-$ 2, heat shock protein-90 (HSP-90) mRNA were designed using Primer 3 plus (Table 1) and PCR was conducted. The PCR productions were confirmed by $2 \%$ agarose gel electrophoresis containing ethidium bromide $(\mathrm{EtBr}, \mathrm{Bi}-$ oneer, Korea) and band images were analyzed by Image J software (Version 1.46; National Institutes of Health, Bethesda, MD, USA).

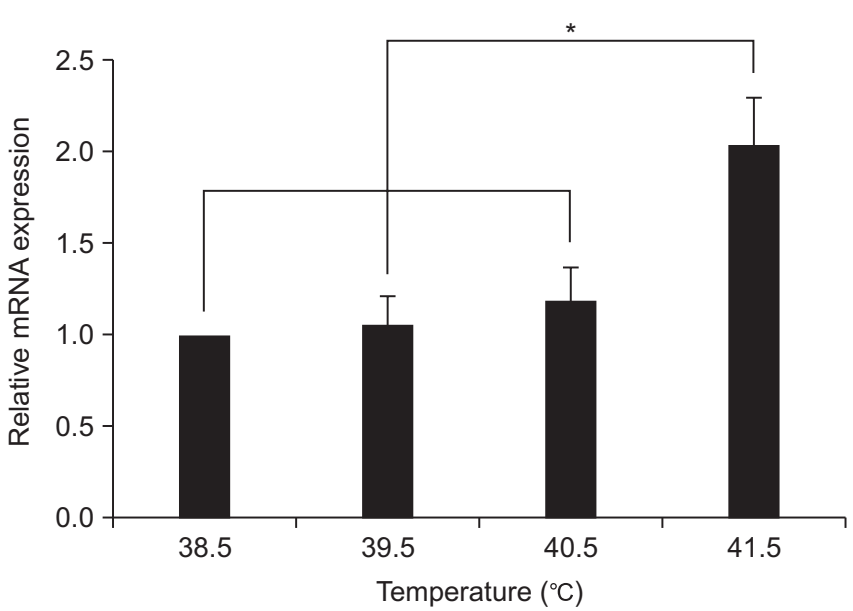

\section{Western blot}

Cultured tissues were homogenized in $200 \mu \mathrm{L}$ mammalian protein extract reagent (M-PER) buffer and rotated for protein extraction at room temperature within $1 \mathrm{~h}$. The resulting homogenate was centrifuged at $12,000 \mathrm{rpm}$ and $4^{\circ} \mathrm{C}$ for $20 \mathrm{~min}$ and the supernatants were collected in a fresh tube. Total protein concentrations were determined according to the method of Bradford. Protein $(50 \mu \mathrm{g})$ was separated by $12 \%$ sodium dodecyl sulfate-polyacrylamide gel electrophoresis (SDS-PAGE) for $90 \mathrm{~min}$ at $150 \mathrm{~V}$ and transferred to polyvinylidene fluoride (PVDF) membranes for $60 \mathrm{~min}$ at $190 \mathrm{~V}$. Membranes were blocked in 5\% skim milk for $45 \mathrm{~min}$ at room temperature and incubated with the following primary antibodies at $4^{\circ} \mathrm{C}$ overnight: rabbit anti-HSP90 (1:1000, Calbiochem, USA), mouse anti- $\beta$-actin (1:500, Novus, USA) and anti-PAI-2 (1:500, Santa Cruz Biotechnology, Santa Cruz, Ca, USA), and goat anti-uPA and anti-PAI-1 (1:500, Santa Cruz Biotechnology). Membranes were washed three times in Tris-buffered saline/tween-20 (TBS-T) and incubated at room temperature for 60 min using the HRP-conjugated secondary antibodies, donkey anti-mouse IgG (1:1000, Santa cruz, USA), donkey anti-goat IgG (1:1000, Santa cruz, USA), and goat anti-rabbit IgG (1:1000, Santa cruz, USA). All proteins were visualized using the West Save ECL kit (Ab frontier) and detected using a gel documentation system and image
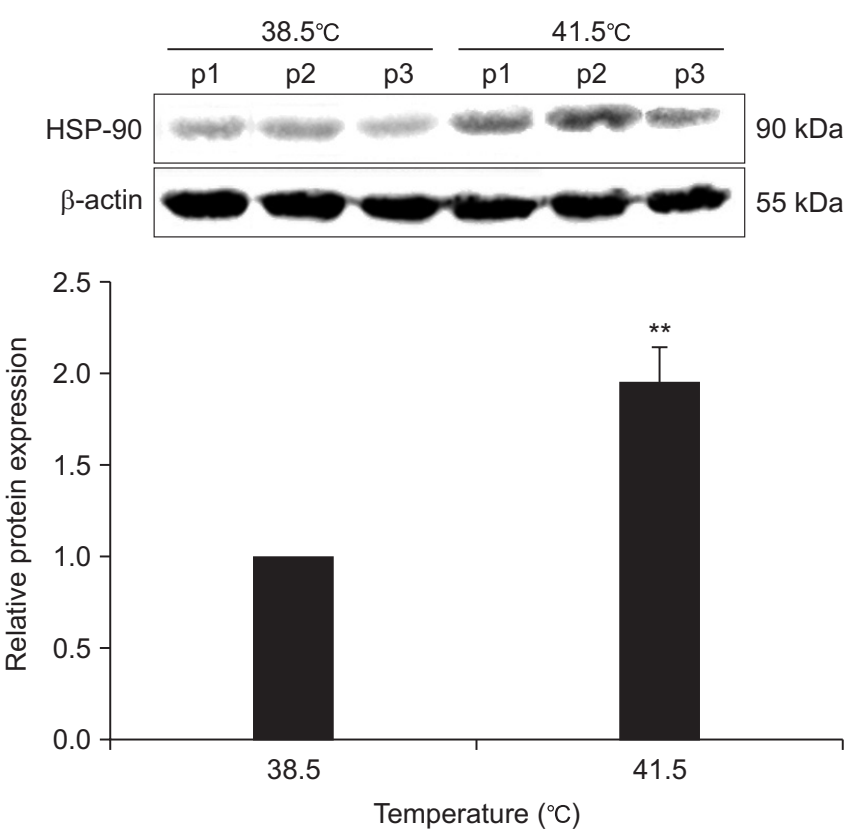

Fig. 1. The expression of heat shock protein-90 (HSP-90) mRNA and protein in porcine endometrial tissues exposed to different temperature $\left(38.5,39.5,40.5\right.$ and $\left.41.5^{\circ} \mathrm{C}\right)$. Asterisk indicates significant differences $\left({ }^{*} p<0.05,{ }^{* *} p<0.01\right)$. 
J was used for image analysis.

\section{PAs activity assay}

Samples of the collected culture medium $(20 \mu \mathrm{L})$ were dispensed into a 96-well microplate and mixed with 30 $\mu \mathrm{L}$ of a plasminogen working solution $(2.5 \mu \mathrm{g} /$ well plasminogen; Sigma-Aldrich). The solution was incubated at $38^{\circ} \mathrm{C}$ for $1 \mathrm{~h}$. After incubation, $200 \mu \mathrm{L}$ of substrate buffer [0.18 mM Z-L-Lys-SBzl hydrochloride, $0.22 \mathrm{mM} \mathrm{5,5^{ \prime }}$ -dithiobis-(2-nitrobenzoic acid), and 0.01\% Triton X-100] was added and was further incubated at $38^{\circ} \mathrm{C}$ for $1 \mathrm{~h}$. PA activity was determined by absorbance at the wavelength of $405 \mathrm{~nm}$ using a microplate reader.

\section{Statistical analysis}

All numerical data representing each parameter were analyzed using the Statistical Analysis System Software (SAS version 9.4). Data are presented means \pm SEM, and
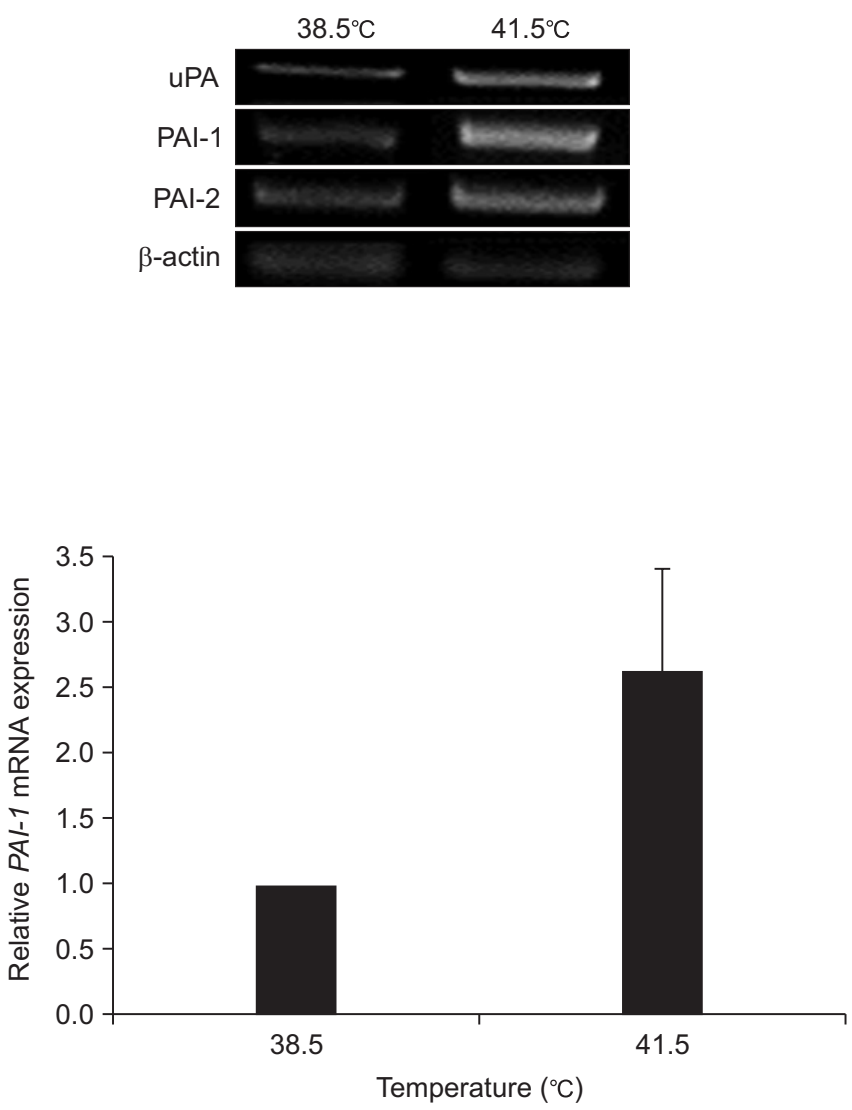

comparisons among treatment groups were conducted by t-test using a generalized linear model (GLM) in the SAS package. A value of $p<0.05$ was considered to indicate a statistically significant difference.

\section{RESULTS}

\section{Expression of HSP-90 mRNA and protein in heat stress-exposed explants}

To confirm temperature that heat stress is induced in porcine endometrial tissue, mRNA and protein levels of HSP-90 were measured (Fig. 1). The expression of HSP90 mRNA was higher in $41.5^{\circ} \mathrm{C}$-exposed tissue than other treatment groups $\left(38.5,39.5\right.$ and $\left.40.5^{\circ} \mathrm{C}\right)(p<0.05)$. Heat stress in $41.5^{\circ} \mathrm{C}$ culture condition increased HSP-90 protein compared with control group as well as mRNA expression $(p<0.05)$.
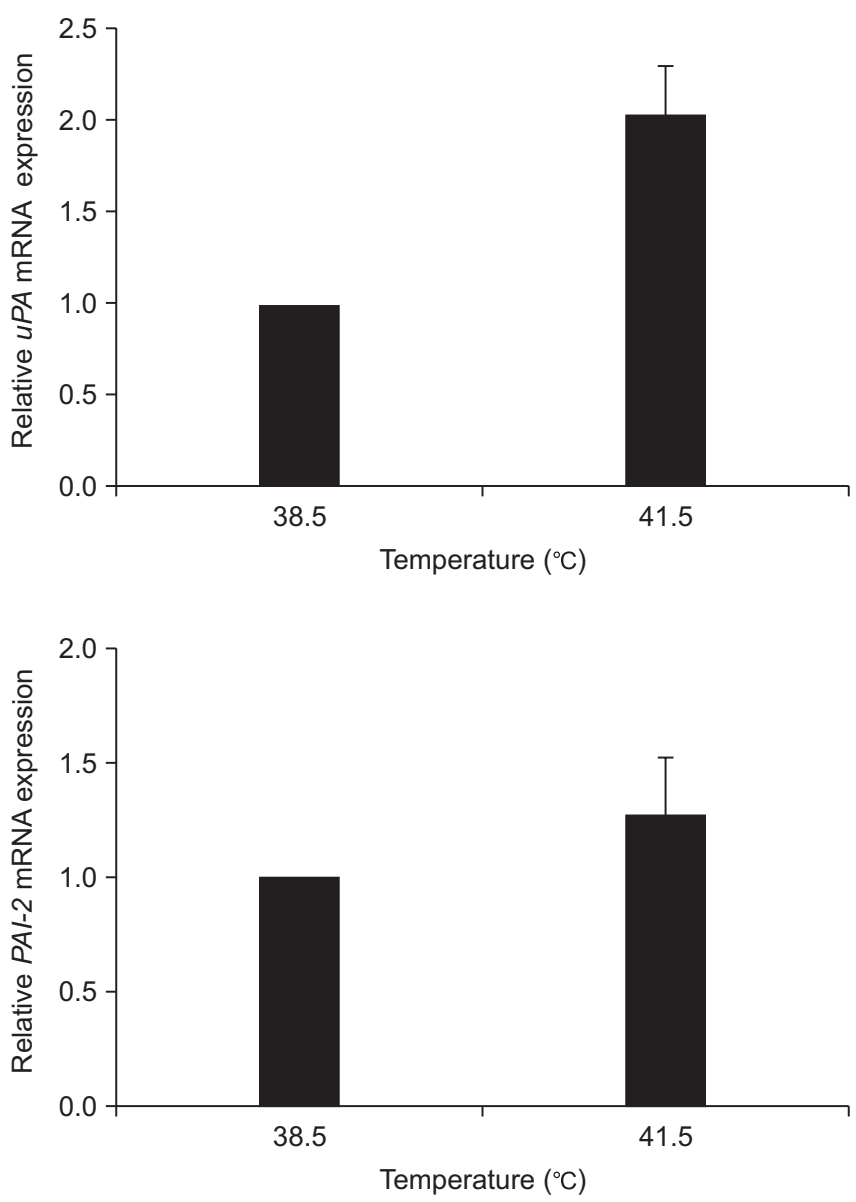

Fig. 2. Effect of heat stress on urokinase-type plasminogen activator (UPA), type-1 PA inhibitor (PAl-1) and type-2 PA inhibitor (PAl-2) mRNA in porcine endometrial tissues exposed to different temperature ( 38.5 and $41.5^{\circ} \mathrm{C}$ ). 


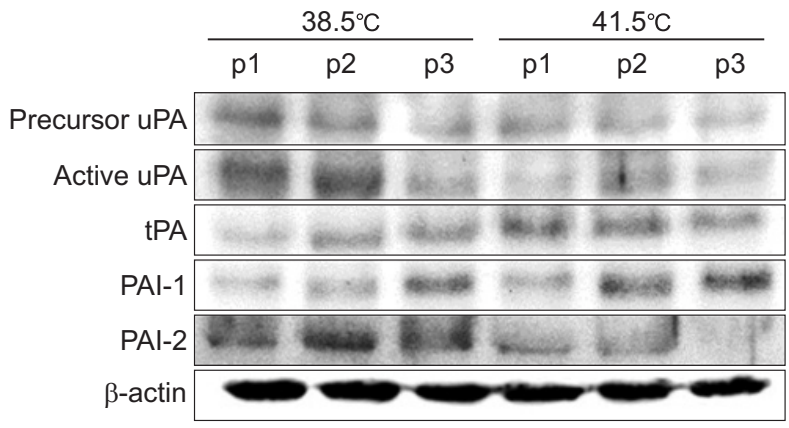

Fig. 3. Change of protein levels of urokinase-type plasminogen activator (uPA), tissue-type PA (tPA), type-1 PA inhibitor (PAI-1) and type-2 PA inhibitor (PAI-2) in porcine endometrial tissues by heat stress condition. Asterisk indicates significant differences $\left({ }^{*} p<0.05\right.$ $\left.{ }^{* *} p<0.01\right)$

\section{Change of PAs activity and expression under heat}

\section{stress condition}

The expression level of mRNA and protein of PAs related factors under heat stress condition were showed in Fig. 2 and Fig. 3, respectively. Heat stress treatment slightly increased $u P A, P A I-1$, and PAI-2 mRNA ( $T P A$ mRNA did not detected), but there were no significant difference. Although mRNA levels were not changed by heat stress, activated form of UPA and PAI-2 proteins were reduced in treatment group ( $p<0.05)$, whereas PAI-1 protein was increased by heat stress (Fig. 4, $p<0.01$ ). Interestingly, PAs activity in supernatants from heat stress-exposed explants was greatly higher than control group $(p<0.05)$ and this activity pattern was not corresponded with protein expression pattern.
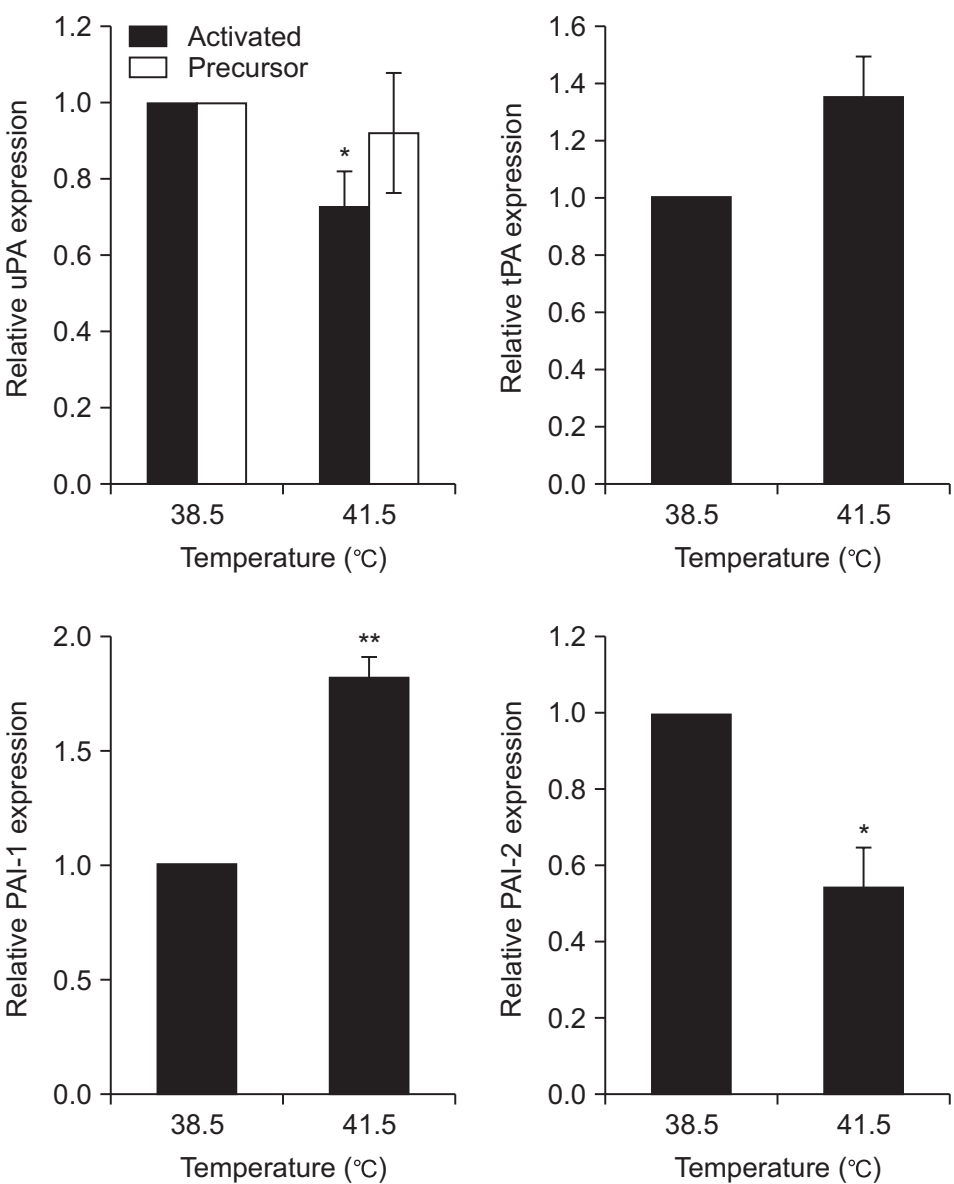


\section{DISCUSSION}

This present study was conducted to confirm effect of heat stress on expression of two-types of PAs and PAIs, and change of PAs activity in porcine endometrial tissues. The expression of HSP-90 mRNA and protein was significantly increased in cultured explants with $41.5^{\circ} \mathrm{C}$ condition. All of mRNA were did not affected by heat stress in tissues. Protein level of uPA and PAI-2 were suppressed in heat stress-exposed tissues, whereas PAI-1 was stimulated. Despite upregulation of PAI-1 and downregulation of UPA, PAs activity was increased by heat stress.

Ambient temperature and light duration that are increased in the summer are directly affect to reproductive performance in pigs. In the domestic animals, continuous exposure by high temperature led to reduce milk production, growth rate of litters and feed intake (Schoenherr et al., 1989). In particular, feed intake in pigs is closely related with various reproductive phenomenon including activity and steroid hormone concentration in ovary, activation of aromatase, delayed ovulation, and reduction of luteinizing hormone receptor (Dourmad et al., 1994). Also, heat stress is caused disruption of oocytes function, decreased embryo development and reduction of steroid hormone secretion in cows (Roth et al., 2001; Sartori et al., 2002). These reports demonstrated that reproduction of mammalians is directly or indirectly influenced by heat stress.

Heat stress is defined as one of stress that occurs as a result of increasing external and internal body temperature. In present study, both of mRNA and protein expression of HSP-90 were increased in $41.5^{\circ} \mathrm{C}$-exposed explants, especially, mRNA expression in $41.5^{\circ} \mathrm{C}$-exposed explants was higher than other temperature groups. Commonly, pigs maintain their body temperature around $37.8-40.7^{\circ} \mathrm{C}$ (Li et al., 2015) and HSPs are produced by cells in response to exposure to stressful conditions. Thus, this result indicated that heat stress in pigs might be induce by internal temperature up to $41^{\circ} \mathrm{C}$.

As one of female reproductive tracts, uterus plays roles in transport of spermatozoa, embryo development and construction of microenvironment for implantation. These physiological roles of uterus are influenced by change of steroid hormones, cytokines, and gonadotropins. Although mRNA levels of $u P A, P A I-1$ and -2 were not changed by heat stress, protein levels were differently reg- ulated under heat stress condition. Kobayashi et al. (2013) reported that expression of microsomal prostaglandin $\mathrm{E}$ synthase 1 mRNA was enhanced by summer heat stress in bovine oviductal epithelial cells, however, protein level of prostaglandin E2 was not altered. Therefore, heat stress in uterus and oviduct would selectively regulate transcription or translation process.

Rensis and Scaramuzzi (2003) reported that blood flow into uterus in cows was reduced by increasing of intrauterine temperature. As one of proteases for tissue remodeling, plasmin, which is converted by PAs, play an important role in angiogenesis. In this study, heat stress in $41.5^{\circ} \mathrm{C}$ condition reduced protein level of UPA and PAI-2, and increased PAI-1 protein. These expression pattern of PAs was seem to be correspond with reduced blood flow through suppression of angiogenesis. However, activation of PAs was greatly stimulated by heat stress. In regulatory mechanism of PAs activity, steroid hormones and various factors such as $\alpha 2$-anitiplasmin, $\alpha 2$-macroglobulin, Kalikrein, Factor XI $\alpha$ and XII $\alpha$ participate in conversion of plasminogen and suppression of plasmin activity. Lee et al. (2014) reported that PAs activity in three-dimensional cultured porcine endometrial cells was suppressed by $17 \beta$-estradiol treatment. Therefore, increased PAs activity by heat stress might be regulated by other regulatory factors and altered steroid hormones, and it is expected that one of responses against reduced blood flow into uterus.

In conclusion, our findings showed that heat stress in porcine endometrium is occurred up to $41.5^{\circ} \mathrm{C}$ conditions and it up-regulated PAs activity in protein level. Increasing of PAs activity might be related with regulation of blood flow into reproductive tracts under heat stress condition, however, regulatory mechanism of PAs activation by heat stress is still unclear. Therefore, investigation of other factors regarding with plasmin activity under heat stress in porcine endometrium is required.

\section{CONFLICTS OF INTEREST}

No potential conflict of interest relevant to this article was reported.

\section{ACKNOWLEDGEMENTS}

This work was supported by the National Research Foundation of Korea (NRF) grant funded by the Ko- 
rea government (Ministry of Education) (2016R1D1A1B03931746).

\section{ORCID}

Yong Hwangbo: https://orcid.org/0000-0003-3636-3551

Hee-Tae Cheong: https://orcid.org/0000-0001-8225-0262

Choon-Keun Park: https://orcid.org/0000-0003-2786-8814

\section{REFERENCES}

Bazer FW. 2013. Pregnancy recognition signaling mechanisms in ruminants and pigs. J Anim Sci Biotechnol. 4:23.

Claus R, Weiler U. 1985. Influence of light and photoperiodicity on pig prolificacy. J Reprod Fertil. [Suppl] 33:199-208.

Dourmad JY, Etienne M, Prunier A, Noblet J. 1994. The effect of energy and protein intake of sows on their longevity: a review. Livest Prod Sci. 40:87-97.

Hansen PJ. 2009. Effects of heat stress on mammalian reproduction. Philos Trans Royal Soc B. 364:3341-3350.

Hwangbo Y, Lee SH, Kim HY, Lee YR, Park JE, Cheong HT, Yang BK, Park CK. 2016. Effects of heat stress on expression of plasminogen activators mRNA and protein in porcine endometrial cells. Ann Anim Resour Sci. 27(3):159-167.

Kobayashi Y, Wakamiya K, Kohka M, Yamamoto Y, Okuda K. 2013. Summer heat stress affects prostaglandin synthesis in the bovine oviduct. Reproduction 146:103-110.

Lee SH, Hwangbo Y, Cha HJ, Kim SJ, Kim MG, Cheong HT, Yang BK, Park CK. 2014. Effect of three dimensional culture of porcine endometrial cell on their plasminogen activity and pre-implantation embryo development after co-culture. J
Anim Reprod Biotechnol. 29:207-219.

Li Y, Zhang ZZ, He CJ, Zhu KF, Xu ZY, Ma T, Tao JL, Liu GS. 2015. Melatonin protects porcine oocyte in vitro maturation from heat stress. J Pineal Res. 59:365-375.

Love RJ, Evans G, Klupiec C. 1993. Seasonal effects on fertility in gilts and sows. J Reprod Fertil. [Suppl] 48:191-206.

Paul C, Teng S, Saunders PT. 2009. A single, mild, transient scrotal heat stress causes hypoxia and oxidative stress in mouse testes, which induces germ cell death. Biol Reprod. 80:913-919.

Peltoniemi OAT, Love RJ, Heinonen M, Tuovinen V, Saloniemi H. 1999. Seasonal and management effects on fertility of the sow: a descriptive study. Anim Reprod Sci. 55:47-61.

Prunier A, Quesnel H, Messias de Braganca M, Kermabon AY. 1996. Environmental and seasonal influences on the return to oestrus after weaning in primiparous sows: a review. Livest Prod Sci. 45:103-110.

Rensis FD, Scaramuzzi RJ. 2003. Heat stress and seasonal effects on reproduction in the dairy cow-a review. Theriogenology 60:1139-1151.

Roth Z, Meidan R, Shaham-Albalancy A, Braw-Tal R, Wolfenson D. 2001. Delayed effect of heat stress on steroid production in medium-sized and preovulatory bovine follicles. Reproduction 121:745-751.

Sartori R, Sartor-Bergfelt R, Mertens SA, Guenther JN, Parrish JJ, Wiltbank MC. 2002. Fertilization and early embryonic development in heifers and lactating cows in summer and lactating and dry cows in winter. J Dairy Sci. 85:2803-2812.

Schoenherr WD, Stahly TS, Cromwell GL. 1989. The effects of dietary fat or fiber addition on yield and composition of milk from sows housed in a warm or hot environment. J Anim Sci. 67:482-495. 